Psychology of Language and Communication 2021, Vol. 25, No. 1

Sciendo

DOI: $10.2478 /$ plc-2021-0006

\author{
Isabel Iñigo-Mora \\ University of Seville
}

\title{
Commitment to the truth or defensive stance? Political strategies in the Brexit contest
}

\begin{abstract}
This paper analyses politicians' selection of adverbs of certainty and extreme case formulations (ECFs) in both the 1975 Referendum and the Brexit (2016). This analysis helped discover if politicians in the 1975 Referendum and the Brexit: (a) framed a similar or different reality through their discourse choices and (b) used the same types of adverbs of certainty and ECFs and with the same frequency. For this purpose, we contrasted both the time (the 1975 Referendum vs. the Brexit) and the position (Anti-Europe vs. Pro-Europe). The corpus was made up of eight different recordings. Four of them were about the Brexit and four about the 1975 Referendum. In the case of the Brexit corpus, two recordings were Pro-Europe, two were Anti-Europe, and the same was in the case of the 1975 Referendum corpus.
\end{abstract}

Key words: political discourse, Brexit, adverbs of certainty, extreme case formulations, 1975 Referedum.

Address for correspondence: Isabel Inigo-Mora, University of Seville, English Language Department, University of Seville, C/Palos de la Frontera, s/n, 41004-Sevilla, Spain.

E-mail: isabelin@us.es

This is an open access article licensed under the CC BY NC ND 4.0 License. 
As Edwards (2004, p. 260) states, "people are shown to formulate or work up the nature of events, actions, and their own accountability, through ways of talking. These "ways of talking" are constructive and action-oriented." This means that people do build the world they live in through their selection of words. Keeping this in mind, we contrasted two actions (commitment to the truth and defensive stance) in one particular scenario: the Brexit contest. For this purpose, we analyzed politicians' selection of adverbs of certainty and extreme case formulations (ECFs) in both the 1975 Referendum and the Brexit (2016). We contrasted both the time (the 1975 Referendum vs. the Brexit) and the position ("Anti" vs. "Pro" Europe positions). Thus, the main goal of this paper was to discover if politicians in the 1975 Referendum and the Brexit: (a) framed a similar or different reality through their discourse choices; and (b) used the same types of adverbs of certainty and ECFs and with the same frequency.

All these politicians share a common reality: the British political contest against or in favor of Europe. As Perloff (2018) points out when talking about political communication, the key element in most political contexts is power. According to Joseph Nye (a US political analyst), there are two different types of power: hard and soft power. Whereas the first one is related to military and economic power, the second is defined as the power of "getting others to want what you want" (Nye, 2004, p. 5). Nye also explains that the "effective study of international politics depends today upon our understanding of the interplay between $[\ldots]$ the politics of territory, guns or money and the language of narrating the world in coherent and persuasive stories." (Chouliaraki, 2005, p. 2). So, the way we narrate the world frames the world we live in. It is for this reason that we have compared the similarities and/or differences in the way in which these politicians framed that particular reality through their specific selection of words regarding the adverbs of certainty and the ECFs.

In this particular political context, extreme attitudes are common because "conflict can breed attitude extremity, which in turn serves to maintain or increase conflict." (Abelson, 1995, p. 25). For this reason, we have decided to focus our attention on discourse choices that are related to attitudinal intensity and strength. As Krosnick and Petty (1995, p. 11) explain "investigators have presumed that attitudinal intensity can be measured via certainty (Brim, 1955; Guttman \& Suchman, 1947; Katz, 1944; McDill, 1959; Suchman, 1950) or extremity (McDill, 1959; Tannenbaum, 1956)." So, an in-depth analysis of the specific discourse strategies used to express certainty and extremity could be very productive.

According to Krosnick and Petty (1995, p. 7), "attitude certainty refers to the degree to which an individual is confident in his or her attitude toward an object." A very common linguistic category that is clearly related to the expression of certainty and confidence is the adverb of certainty. As Simon-Vandenbergen and Aijmer (2007) explain (p. 69), "adverbs should express the speaker's strong commitment to the truth of the proposition, i.e. that they should express a rather 
high degree of probability." So, some adverbs might express strong conviction and some others - weaker ones. Additionally, their use might depend on contextual reasons. Thus, we believe it could be quite revealing to research into their use in one specific scenario: the British political contest against or in favor of Europe. We followed a selection of the modal adverbs of certainty from the ICE-GB (International Corpus of English-Great Britain) that Simon-Vandenbergen and Aijmer (2007, p. 69) offered in their study.

Additionally, Edwards (2000, p. 347-348) explains that ECFs are "descriptions or assessments that deploy extreme expressions such as every, all, none, best, least, as good as it gets, always, perfectly, brand new, and absolutely." Pomerantz (1986, p. 227) summarizes the three main uses of ECFs in the following way:

(1) to assert the strongest case in anticipation of nonsympathetic hearings,

(2) to propose the cause of a phenomenon,

(3) to speak for the rightness (wrongness) of a practice.

In both cases (i.e., adverbs of certainty and ECFs), they are not only indexing the speaker's stance or attitude but also "a state of affairs is portrayed as believable, obvious, compelling" (Pomerantz, 1986, p. 219). For this reason, we believe that a contrastive study of both could be very revealing when detailing what kind of reality these politicians are building in their contest. In this specific study, we analyzed ECFs such as those that express negation, globalism, or exclusiveness and also adverbs of frequency/degree/manner, adjectives, numbers, and nouns that convey some kind of extreme description or assessment.

First of all, we provide a brief introduction to the main characteristics that feature political communication. Then, we offer a brief review of the main traits and uses of both the expressions of certainty (adverbs of certainty) and ECFs. Next, a brief summary about the Brexit contest is offered. Subsequently, we provide an account of the methodology we have followed. Afterwards, a detailed explanation of the results of our analysis is presented. Finally, we finish with our conclusions.

\section{Political Communication}

The term "political communication" seems, at first, difficult to be defined. In this sense, Denton and Woodward (1990) identify the senders' intention to influence the political setting as the key defining element in political communication. Perloff $(2018$, p. 30) also includes this element in the following definition of political communication:

Political communication is the process by which language and symbols, employed by leaders, media, or citizens, exert intended or unintended effects on the political cognitions, attitudes, or behaviors of individuals or on outcomes that bear on the public policy of a nation, state, or community. 
Similarly, Ball (2011,p. 42) describes political communication as "the practice of using language to move people to think and act in ways that they might not otherwise think and act." So, the language used in political communication could be described as a "powerful language," a language with "colourful phrases, apt metaphors, syntax and rhythm" with the main purpose of "molding attitudes and move citizens" (Perloff 2018, p. 30). For this reason, McNair (2011) establishes a very reasonable comparison between commercial marketing and political marketing as they both share the main goal: to market a product in the case of the first one and to sell an idea in the case of the second. Only powerful political actors with a powerful language can sell their ideas. Additionally, politics is a fight for power. As Perloff (2018, p. 35) explains, "leaders invoke language, symbols, and the trappings of their offices to gain and maintain power."

To be more specific, in this paper, we followed Denton and Woodward (1990) and McNair (2011) in identifying political communication as purposeful communication embracing the following elements (McNair, 2011): (a) all forms of communication with politicians and other political actors who wish to reach some specific goals, (b) communication aimed at these actors by nonpoliticians (i.e., citizens, newspaper columnists, etc.), and (c) communication about these actors and their actions, mainly by media coverage. As McNair (2011) explains, in this scenario, we can distinguish: political organizations (parties, public organizations, pressure groups, terrorist organizations and governments), the media, and citizens. They all play an essential role in political communication because, as Perloff (2018, p, 35) points out, "leaders, media, and citizens symbolically joust among themselves and fram[e] problems in different ways." A key idea here is that of framing. According to Entman (1993, p. 52) framing:

... essentially involves selection and salience. To frame is to select some aspects of a perceived reality and make them more salient in a communicating text, in such a way as to promote a particular problem definition, causal interpretation, moral evaluation, and/or treatment recommendation for the item described.

In this way, as Scheufele (1999) argues, framing is a kind of social constructivism because individuals can frame their own reality. This is particularly evident in the case of political communication. As Kaid et al. (1991) defend, political reality is made up of three important categories: an objective reality (actual events), a subjective reality (individuals' perceptions), and a constructed reality (events presented by the media). As a matter of fact, the media plays a determining role in the process of framing. As Perloff (2018, p. 35) explains, "the news media's choice of issues, and the way they frame the news, can influence leaders and the public." When talking about the conventional media (newspapers, magazines, and television), Perloff (2018, p. 41) added that "they convey a message to the audience, ignoring, selecting, shaping, and framing information 
based on a host of factors." In this sense, the Internet's role as an extremely important source of information that might frame the individuals' reality must be emphasized. As Zhuravskaya et al. (2020, p. 416) explain:

Many commentators suggest that the Internet in general, and social media in particular, plays a key role in amplifying economic, political, and cultural grievances across the globe and, perhaps even more important, that they have their own independent effects on politics in both established democracies and autocratic regimes.

In this sense, social media's role in the results of the Brexit Referendum (2016) is particularly important. Gorodnichenko et al. (2018) explored the diffusion of information on Twitter during the Brexit Referendum and the 2016 U.S. Presidential Election. Their results show that the aggressive use of Twitter bots could have contributed to the vote outcomes. As Hänska and Bauchowitz (2017) indicated, social media is a channel not only for users (meaning regular citizens), but also for journalists and politicians. As a matter of fact, as they point out, 87\% of British MPs have Twitter accounts. Hänska and Bauchowitz (2017, p. 29) conclude in their study that:

It is clear from our analysis that Twitter users who supported leaving the EU were more numerous, and Eurosceptic users in general were more active (they tweeted more frequently) than Remain users [...] Other researchers examining Google Search trends, Instagram posts and Facebook found similar patterns of Eurosceptic views being communicated with greater intensity by a greater number of users on those platforms (Herrman, 2016, Polonski, 2016).

Press coverage also played a determining role in the results of the Brexit Referendum. As Hänska and Bauchowitz (2017, p. 30) explain, they "also favored leaving the EU. Weighted for circulation, 82 percent of newspaper articles in the lead-up to the Referendum supported leaving the EU." Similar results have also been presented by Deacon (2016).

\section{The Expression of Certainty: Adverbs of Certainty}

As Simon-Vandenbergen and Aijmer (2007, p. 1) state, "modality has always been a fascinating area to philosophers, logicians as well as linguists, and has been approached from a large number of different perspectives." English shows a wide variety of resources to communicate modality: modal nouns (Akiba, 2016; Ilkhanipour, 2016), adjectives (Van linden, 2012), adverbs (Rozumko, 2017; Velasquez, 2014), modal auxiliaries (Biber et al., 1999; Coates, 1983; Huddleston \& Pullum, 2002; Palmer, 1990; Quirk et al., 1985) and lexical verbs (DontchevaNavratilova, 2018; Salazar \& Verdaguer, 2009;). Zhang (2019, p. 879) explains that: 
Assertion deals with factual propositions based on the real knowledge of the worlds, while modality focuses on the necessities and possibilities of the proposition. Modality is an important semantic category that attracts many scholars' interest. Many expressions in our lives are related to modality. Modality often deals with possibility and necessity.

The relationship that Simon-Vandenbergen and Aijmer (2007) establish between epistemic certainty and evidentiality is particularly important. As they explain, many linguists set forth that "speakers' commitment to the truth value of their utterance is to be taken for granted in communication, and hence that expressions of certainty are either superfluous or signal something else." (p. 2). This idea has generated important doubts and "it signals the problem of why people express certainty" (p. 2). This is the main reason why Simon-Vandenbergen and Aijmer (2007) endeavored to offer a full description of modal certainty, and more specifically, modal adverbs as they are used in present-day English. As SimonVandenbergen and Aijmer explain (2007, p. 69), "adverbs should express the speaker's strong commitment to the truth of the proposition, i.e., that they should express a rather high degree of probability." It is obvious that it is a matter of degrees. Some adverbs might express strong conviction and some others weaker ones. It is also convenient to highlight that their use might depend on contextual reasons. Simon-Vandenbergen and Aijmer (2007, p. 69) offer a table of the modal adverbs of certainty in the ICE-GB (International Corpus of English-Great Britain). The following adverbs are considered in this table: of course; certainly; obviously (manner not included); indeed; clearly (manner not included); no doubt; definitely; necessarily; surely; undoubtedly; naturally; inevitably; plainly; evidently; arguably; for sure; admittedly; for certain; decidedly; undeniably; unquestionably. Simon-Vandenbergen and Aijmer (2007, p. 69) list them in order of frequency.

As it was previously pointed out, the use of these modals adverbs clearly depends on the context and type of social activity (social roles, power, etc.). As Simon-Vandenbergen and Aijmer (2007, p. 5) clearly state, "with this study we hope to contribute to the discussion on the association between individual speaker's 'small' choices from the repertoire of modal certainty expressions and "large" issues such as societal relations." This idea is intrinsically linked to our goal in this paper: We examined if there is any connection between a speaker's choice of adverbs of certainty and the specific context in which they are being used, more specifically, the political arena.

\section{Defending a Position: Extreme Case Formulations}

As it was stated above, it seems that many investigators (Brim, 1955; Guttman \& Suchman, 1947; Katz, 1944; Krosnick \& Petty, 1995; McDill, 1959; Suchman, 1950; Tannenbaum, 1956) assume that attitudinal intensity can be measured via certainty or extremity. So, there is a solid relationship between certainty and 
extremity. According to Krosnick and Petty $(1995$, p. 6$)$ "extremity is the extent to which the attitude deviates from neutrality. The more extreme an attitude is, the more an individual likes or dislikes the object." For this reason, we believe that there is a strong connection with what Pomerantz (1986) calls ECFs. As Edwards and Potter (1992) defend, discourse is an ongoing activity constructing and making relevant the participants' emotional feelings and attitudes. These attitudes are examined as evaluative practices done in discourse. For this reason, we believe that it would be quite revealing to check if our speakers' attitudes (politicians in the Brexit contest in this case) are much more concerned with the expression of certainty or with the defense of a stance in an extreme way.

Whitehead (2015) adds two more functions: (a) to index a speaker's investment in a claim, to upgrade a prior assessment; and (b) to exaggerate, tease, ironize and joke.

Finally, as it has already been pointed out in Iñigo-Mora (2007), politicians seem to favor this kind of language. Iñigo-Mora (2007) carried out a case study in which she contrasted the ECFs used in nine English panel interviews (about political, socio-political, and social issues) and four political pre-electoral debates. She concluded that

the number of ECFs found in the Spanish and in the English corpora differs considerably ... And in relation to the type of recording, the data reveal that (a) interviewers and interviewees deployed many more ECFs in political recordings (2.8 percent) than in social-political (1.2 percent) or social recordings (1.3 percent); and (b) politicians used more ECFs (4.8 percent) than any other type of interviewees (1.5 percent; p. 341).

\section{The Brexit Contest}

In 1973, the United Kingdom (UK) joined the European Union (EU), but as Tendera-Właszczuk (2018, p. 307) explains, "from the very beginning the UK membership in the EU has been marked by many tensions. One of the most important problem was the discussion on the future model of the integration." This has provoked an important dichotomy between Pro-European (normally associated to Labour party) and Anti-European (normally associated to Conservative party) ideologies. These two contrasting views have originated two important plebiscites: the 1975 Referendum and the Brexit (2016). The results of these two plebiscites have been completely different. In the case of the 1975 Referendum, it ended up with the decision of staying in the Common Market ( $68 \%$ of all voters wanted to stay). In the case of the Brexit referendum, the results led the UK to leave the EU ( $52 \%$ of the voters chose to leave the EU). In the 1975 Referendum, the question was: "Do you think the UK should stay in the EU (the Common Market)? In the Brexit the question was "Should the United Kingdom remain a member of the European Union or leave the European Union?" 
There are many studies (Campos et al., 2014; Minford, 2006; Pain \& Young, 2004; Ottaviano et al., 2014) that concluded that joining a monetary union was beneficial to the United Kingdom. We suppose that those potential benefits were the reason why, in 1975, the British society decided to stay in the Common Market. So, what provoked such a change of opinion in 2016? Melkumian $(2018$, p. 40) found that "changing demographic trend - the aging of the UK population - is the reason for the "Leave the Union" majority vote in 2016 Referendum." Melkumian (2018, p. 42) shows in two very illustrating tables the revealing differences in the demographic profile referendum voting in 1975 and 2016 by age (voters only). Whereas most "over 65" voters (70\%) voted YES (stay) in 1975, most "over 65" $(61 \%)$ voted NO (leave) in 2016. Melkumian $(2018$, p. 42) points out that:

Voters in the age group of 18-24 were born into the European Union and enjoyed the benefits of unification their entire life. For them, separating from the EU is going back in time, regressing into separation and isolation The youngest voters in 1975 would currently (the year of 2016 vote) be in 61+ years of age group. And these voters will be captured in the last two columns of Table 2: age 50-64 and 65-. And these two columns show a very determined vote to leave the European Union (56\% and $61 \%$ voted to leave the EU in the respective age groups of 50-64 and 65-) ... It suggests that expectations of the young people voting "yes" to the unification in 1975 were not met. It suggests disappointment in and resentment towards the Union or the policies the UK had to adapt and follow as the Union member.

It is difficult to pinpoint the reason(s) for this decision to leave the EU, but the numbers show that a large number of disappointed elderly people have influenced a lot the future of young Britons. As Melkumian (2018, p. 44) concludes, "the major reason for the older voters choosing "To leave the EU" was their increasing degree of relative risk aversion to uncertainties brought into their lives by the membership in the European Union."

\section{Methodology}

The corpus was made up of eight different recordings. Four of them were about the Brexit and four about the 1975 Referendum. In each of these two sets, two recordings were Pro-European and two were Anti-European. Additionally, two recordings were parliamentary speeches and two were political interviews. Each recording was around 5 minutes long. Tables 1 and 2 present a summary of this descriptive data:

Since the corpus contained sharply opposite views (Pro-European vs. AntiEuropean), we analyzed absolute expressions of opinion: (a) all ECFs expressions and (b) all adverbs of certainty included in Simon-Vandenbergen and Aijmer's table (2007, p. 69). We contrasted the rate of use of both (i.e., ECFs vs. adverbs 
of certainty) and focused on possible differences and/or similarities, taking into account the time of the event (Brexit vs. 1975 Referendum) and the positions (ProEuropean vs. Anti-European).

As the recordings were not of the same length, we decided to use ratios, taking into account the number of words. Specifically, we calculated the number of adverbs of certainty and ECFs for every one hundred words of the transcript. In this way, the results are biased by the differences in the total length of each transcript.

\section{Results and Discussion}

We first contrasted the ratio of adverbs of certainty included in SimonVandenbergen and Aijmer's table (2007, p. 69) and ECFs (see Tables 3 and 4). The first difference was the low rate of adverbs of certainty (0.17) in contrast to high the rate of ECFs (1.03). This shows that politicians, no matter the time (The 1975 Referendum or The Brexit) or position (Anti-European or Pro-European), are more prone to display extreme opinions than to demonstrate certainty.

\begin{tabular}{|l|c|c|c|c|c|c|}
\hline \multicolumn{2}{|l|}{ Table 1. The 1975 Referendum recordings. } \\
\hline Politician & $\begin{array}{c}\text { Political } \\
\text { affiliation }\end{array}$ & Position & $\begin{array}{c}\text { Type of } \\
\text { recording }\end{array}$ & Date & $\begin{array}{c}\text { Number } \\
\text { of words }\end{array}$ & Duration \\
\hline $\begin{array}{l}\text { Harold } \\
\text { Wilson }\end{array}$ & Labour & $\begin{array}{c}\text { Pro- } \\
\text { European }\end{array}$ & Interview & 15.05 .1975 & 840 & $\begin{array}{c}4 \mathrm{~min} \\
53 \mathrm{~s}\end{array}$ \\
\hline $\begin{array}{l}\text { Edward } \\
\text { Heath }^{2}\end{array}$ & Conservative & $\begin{array}{c}\text { Pro- } \\
\text { European }\end{array}$ & $\begin{array}{c}\text { Parliamentary } \\
\text { speech }\end{array}$ & 05.06 .1975 & 684 & 4 min \\
\hline Tony Benn $^{3}$ & Conservative & $\begin{array}{c}\text { Anti- } \\
\text { European }\end{array}$ & Interview & $1990^{*}$ & 777 & 4 min $5 \mathrm{~s}$ \\
\hline Peter Shore $^{4}$ & Labour & $\begin{array}{c}\text { Anti- } \\
\text { European }\end{array}$ & $\begin{array}{c}\text { Parliamentary } \\
\text { speech }\end{array}$ & 05.06 .1975 & 652 & 4 min $6 \mathrm{~s}$ \\
\hline
\end{tabular}

\begin{tabular}{|l|c|c|c|c|c|c|}
\hline Table 2. The Brexit recordings. & $\begin{array}{l}\text { Political } \\
\text { affiliation }\end{array}$ & Position & $\begin{array}{c}\text { Type of } \\
\text { recording }\end{array}$ & Date & $\begin{array}{c}\text { Number of } \\
\text { words }\end{array}$ & Duration \\
\hline $\begin{array}{l}\text { Jeremy } \\
\text { Corbyn }\end{array}$ & Labour & $\begin{array}{c}\text { Pro- } \\
\text { European }\end{array}$ & $\begin{array}{c}\text { Parliamentary } \\
\text { speech }\end{array}$ & 11.12 .2017 & 549 & 5 min $30 \mathrm{~s}$ \\
\hline Tony Blair & Labour & $\begin{array}{c}\text { Pro- } \\
\text { European }\end{array}$ & Interview & 10.09 .2017 & 1017 & 5 min $29 \mathrm{~s}$ \\
\hline $\begin{array}{l}\text { Boris } \\
\text { Johnson }\end{array}$ & Conservative & $\begin{array}{c}\text { Anti- } \\
\text { European }\end{array}$ & Interview & 06.03 .2016 & 847 & 5 min $7 \mathrm{~s}$ \\
\hline $\begin{array}{l}\text { Theresa } \\
\text { May }^{8}\end{array}$ & Conservative & $\begin{array}{c}\text { Anti- } \\
\text { European }\end{array}$ & $\begin{array}{c}\text { Parliamentary } \\
\text { speech }\end{array}$ & 11.12 .2017 & 940 & 6 min $10 \mathrm{~s}$ \\
\hline
\end{tabular}

1 https://www.youtube.com/watch?v=7W67Xppg434

$2 \mathrm{https} / / / \mathrm{www}$.youtube.com/watch? $\mathrm{v}=\mathrm{I} 2 \mathrm{jUY}$ YryRYII\&t $=4715 \mathrm{~s}$

3 https://www.youtube.com/watch?v=LzJEzO3AMOQ. Tony Benn on Clive Anderson Talks.

4 https://www.youtube.com/watch?v=I2jUYryRYII

5 https://www.youtube.com/watch?v=CnSn9wwcyuU\&t=1053s

6 https://www.youtube.com/watch? $\mathrm{v}=\mathrm{sAUW} 8 \mathrm{rBXD} 80 \& \mathrm{t}=329 \mathrm{~s}$. The BBC's Andrew Marr Show BBC One.

7 https://www.youtube.com/watch?v=7IWOjb86-EM

8 https://www.youtube.com/watch? $\mathrm{v}=\mathrm{CnSn} 9 \mathrm{wwcyuU} \& \mathrm{t}=1053 \mathrm{~s} / / \mathrm{https} / /$ /hansard.parliament.uk/ 


\begin{tabular}{|l|c|c|c|}
\hline \multicolumn{1}{|c|}{ Table 3. Ratio of adverbs of certainty. } \\
\hline \multirow{2}{*}{ Position } & Type of corpus & $\begin{array}{c}\text { Number of adverbs of } \\
\text { certainty }\end{array}$ & Ratio \\
\hline \multirow{2}{*}{ Pro-European } & $\begin{array}{c}\text { The } 1975 \text { Referendum } \\
\text { corpus }\end{array}$ & 1 & 0.07 \\
\cline { 2 - 4 } & The Brexit corpus & 4 & 0.22 \\
\hline Total & $\begin{array}{c}\text { The } 1975 \text { Referendum } \\
\text { corpus }\end{array}$ & 3 & 0.19 \\
\cline { 2 - 4 } & The Brexit corpus & 3 & 0.19 \\
\hline
\end{tabular}

\begin{tabular}{|l|c|c|c|}
\hline \multicolumn{1}{|l|}{ Table 4. Ratio of extreme case formulations } \\
\hline Position & Type of corpus & Number of ECFs & Ratio \\
\hline \multirow{3}{*}{ Anti-European } & $\begin{array}{c}\text { The } 1975 \text { Referendum } \\
\text { corpus }\end{array}$ & 23 & 1.61 \\
\cline { 2 - 4 } & The Brexit corpus & 17 & 0.95 \\
\hline \multirow{3}{*}{ Pro-European } & $\begin{array}{c}\text { The 1975 Referendum } \\
\text { corpus }\end{array}$ & 15 & 0.99 \\
\cline { 2 - 4 } & The Brexit corpus & 10 & 0.64 \\
\hline Total & & 65 & 1.03 \\
\hline
\end{tabular}

\section{Adverbs of Certainty}

A difference between the overall rate of adverbs of certainty in the AntiEuropean position (0.15) and the Pro-European position (0.19) was also revealed (see Table 5). Those who were in the Pro-European position were more prone to show certainty, perhaps because they want to show a "sure and solid" way towards Europe. Peter Shore explained in a parliamentary speech (05.06.1975) that British people should be free to make their laws and should not allow "third countries" to interfere into Britons' issues, and he compared that situation with the relation between Canada and USA, as they both have commercial relations, but they do not interfere in the laws of the other country. Peter Shore says:

Do you think Canada, 22 million of people, and to the south a great and friendly nation - yes, they are - but do you think Canada is going to allow its laws to be written by the 200 million people in some union in America? No, no - of course not.

In order to show complete certainty about his argument, at the end of his speech, he used a definite "of course" which communicates absolute selfconfidence.

Table 6 shows the ratio of adverbs of certainty in both plebiscites. The difference in the ratio of adverbs of certainty used in the 1975 Referendum recording set $(0.13)$ and in the Brexit recording set $(0.21)$ is notable. According to Gross et al. (1995), many factors affect attitude certainty. They mention some external factors (informational/cognitive and social/consensual) and some 


\begin{tabular}{|c|c|c|c|}
\hline Table 5. Adverbs of certainty in the Anti- and in Pro-European positions. \\
\hline Position & Number of words & $\begin{array}{c}\text { Number of adverbs of } \\
\text { certainty }\end{array}$ & Ratio \\
\hline Anti-European & 3216 & 5 & 0.15 \\
\hline Pro-European & 3090 & 6 & 0.19 \\
\hline Total & 6306 & 11 & 0.17 \\
\hline
\end{tabular}

\begin{tabular}{|c|c|c|c|}
\hline \multicolumn{5}{|c|}{ Table 6. Ratio of adverbs of certainty in both plebiscites. } \\
\hline Type of corpus & Number of words & Number of adverbs & Ratio \\
\hline $\begin{array}{c}\text { The } 1975 \text { Referendum } \\
\text { corpus }\end{array}$ & 2953 & 4 & 0.13 \\
\hline The Brexit corpus & 3353 & 7 & 0.21 \\
\hline Total & 6306 & 11 & 0.17 \\
\hline
\end{tabular}

personal attributes that might determine uncertainty reduction. Among the informational/cognitive factors they mention (p. 220-222) are:

- Knowledge: "Direct experience with an attitude object increases both latitude of rejection and opinion certainty."

- Thought: "Amount of thought, however, need not necessarily increase certainty.

- Accessibility: "Three contributors to attitude accessibility or availability have been considered determinants of confidence: familiarity, internal consistency and salience."

- Framing: "Framing (or cognitive priming) affects certainty."

Concerning social/consensual factors, Gross et al. (1995, p. 223) explain that:

Other theorizing emphasizes the role of consensus in uncertainty reduction discovering that our attitudes are normative [...], shared by people with whom we identify $[\ldots]$ shared by others in informal conversation $[\ldots]$ or shared by those we seek for comparison

All these factors being considered in our specific scenarios (i.e., two plebiscites regarding the same decision), and taking into account the results in Table 6, it can be concluded both knowledge and accessibility regarding the political position of the UK in Europe was higher among British politicians in 2016 than in 1975. That might have provoked the increase in the number of adverbs of certainty in 2016. In 1975, politicians had to face this decision for the very first time, whereas in 2016, they had already had direct experience with this issue and they were familiar with it (i.e., knowledge and familiarity).

Table 7 shows the distribution of adverbs of certainty. It is also notable that the one politician who used more adverbs of certainty than the rest of politicians (no matter the Pro- or Anti-European position) was Boris Johnson (0.35) in his 


\begin{tabular}{|c|c|c|c|c|}
\hline Position & Recordings & Politician & Number of adverbs of certainty & Ratio \\
\hline \multirow{4}{*}{ Anti-European } & \multirow{2}{*}{ The 1975 Referendum } & T. Benn & 0 & 0 \\
\hline & & P. Shore & 1: "of course" & 0.15 \\
\hline & \multirow[t]{2}{*}{ Brexit } & B. Johnson & $\begin{array}{c}\text { 3: "certainly" (x2) and } \\
\text { "obviously" }\end{array}$ & 0.35 \\
\hline & & T. May & 1: "clearly" & 0.11 \\
\hline \multirow{4}{*}{ Pro-European } & \multirow{2}{*}{ The 1975 Referendum } & H. Wilson & 2: "certainly" and "indeed" & 0.24 \\
\hline & & E. Heath & 1: "of course" & 0.15 \\
\hline & \multirow{2}{*}{ Brexit } & J. Corbyn & 1: "of course" & 0.18 \\
\hline & & & 2: "certainly" and "obviously" & 0.19 \\
\hline Total & & & 11 & 0.17 \\
\hline
\end{tabular}

interview. He used the adverb "certainly" twice and in the same sentence when the interviewer asks him "why you have decided now we should be better off outside the EU." Johnson answers:

we would then get a much better deal and when you could end stay in I have to say I think that that is if you certainly true that if you want to leave all your options are good and you could certainly strike a great free trade deal with the European union

In this answer, Johnson is stating his full certainty about the positive consequences of leaving the EU. Perhaps this certainty stance was one of the reasons for his success in the Brexit contest. It could be a coincidence, but the numbers show that those who used adverbs of frequency much more regularly in the 1975 Referendum also won the contest: Pro-European with rates of 0.24 and 0.15 in contrast to Anti-European with rates of 0 and 0.15 . So, it seems that there is a correlation between the frequency of adverbs of certainty and success. The choice we make of the words we use are not just random selections, as discursive psychology (DP) defends (Edwards, 2004, p. 260):

Rather than people having memories, script knowledge, attitudes, etc, that they carry around in their heads and produce on cue (or in research interview), people are shown to formulate or work up the nature of events, actions, and their own accountability, through ways of talking. These "ways of talking" are constructive and action-oriented.

In other words, we build the world we live in through the selection of words we use. This could be a reason why there is a correlation between ways of talking and the construction of realities.

In the following extract taken from May's parliamentary speech, the way she frames her reality can be seen: 
we have argued robustly and clearly for the outcomes we seek: a fair and reciprocal deal that will guarantee the rights of more than 3 million EU citizens living in the UK and 1 million UK nationals living in the EU, so that they can carry on living their lives as before; a fair settlement of the accounts, meeting our rights and obligations as a departing member state in the spirit of our future partnership ... this is conditional upon a number of principles we have negotiated over how we will ultimately arrive at a fair valuation of these commitments ... It is a fair settlement for the British taxpayer, who will soon see significant savings compared with remaining in the European Union ...

May combines two different strategies. First, she advances" that her attitude towards what she is going to explain is one of absolute certainty ("robustly and clearly") and then she repeats up to four times the word "fair:" "a fair and reciprocal deal," "a fair settlement of the accounts," "a fair valuation," and "a fair settlement." In this way, she selects and highlights "some facets of events or issues, and mak[es] connections among them so as to promote a particular interpretation, evaluation, and/or solution." (Entman, 2004, p. 5). The particular interpretation that May is promoting is one of a "clear, complete and fully fair new reality." In other words, she is framing a particular reality she wants to build in her audience's minds: she wants every single member of her audience to share with her the same interpretation of a "fair" new reality in favor of the Brexit. This is a very well-known strategy among politicians, as Perloff (2018, p. 159) indicated: "framing is at the heart of political discourse." According to Kinder (2007, p. 158), "frames suggest how politics should be thought about, thereby encouraging citizens to understand events and issues in particular ways," and as Perloff (2018, p. 159) concludes, "that is the essence of politics".

Similarly, the way in which Wilson frames his reality in the following extract is also highly evident:

Now remember I have never been an emotional European and I don't stand on this south goes look to us they come and you say there's a new Eurozone with that I am if and I am emotion I'm an emotional commonwealth of men it mattered a great deal to me when spontaneously the thirty-three heads of government all of the commonwealth said it matters to them that we stay in the market into some it matters very very much indeed.

As in the previous example, Wilson is also using a twofold strategy, but the other way round. May expressed full certainty and then presented the "fair" characteristics of her reality. Wilson started framing his reality by means of a highly sentimental and moving language: three times emotion(al) and three times "to matter," and concluded with an expression of full certainty (indeed) preceded by an intensifier (very) which was repeated ("very, very much"). In this case he is appealing to his audience's emotions, trying to make them feel and think the way 
he feels and thinks. Two different scenarios (Anti-European May in the Brexit vs. Pro-European Wilson in the 1975 Referendum) used same rhetorical device. As Perloff (2018, p. 159) explains, "information provides the starting point, but frames connect the dots and build critical associations, inviting citizens to view the issue in particular ways."

\section{Extreme Case Formulations}

Table 8 shows the distribution of these ECFs. The most significant conclusion is that the rate of ECFs used in the Anti-European recordings (1.24) was higher than in the Pro-European recordings (0.81; see Table 9).

As Edwards (2000) pointed out, these ECFs index the speaker's stance or attitude. Thus, the Anti-European position could be regarded as an adversarial or defensive stance if we take into account one of the main uses of ECFs according to Pomerantz (1986). So, it seems that the Anti-European position was the most challenging one because it implied a definite break with Europe.

The next step was to analyze what specific types of ECFs were used in these recordings. Did these politicians use similar or different ECFs depending on their positions? Were some ECFs more popular than others? We have grouped all the ECFs according to their similarities and yielded the following results (see Table $10)$ :

This classification is not definite because in some cases, it is not so clear-cut. For example, in the case of never, it could have been included in the group of negation, but also in the group of adverbs of frequency. Another possible problem is that we mixed grammatical categories (nouns, adverbs, and adjectives) with descriptive categories (globalizing and exclusiveness). In this sense, we used

\begin{tabular}{|c|c|c|c|c|}
\hline Table 8. Distribution of extreme case formulations (ECFs). \\
\hline Position & Recordings & Politician & Number of ECFs & Ratio \\
\hline \multirow{4}{*}{ Anti-European } & \multirow{2}{*}{ The 1975 Referendum } & T. Benn & 8 & 1.03 \\
\cline { 3 - 5 } & \multirow{3}{*}{ The Brexit } & P. Shore & 15 & 2.3 \\
\cline { 3 - 5 } & & \multirow{2}{*}{ B. Johnson } & 5 & 0.6 \\
\cline { 3 - 5 } & \multirow{3}{*}{ Pro-European } & T. May & 12 & 1.3 \\
\cline { 3 - 5 } & \multirow{2}{*}{ The 1975 Referendum } & H. Wilson & 9 & 1.1 \\
\cline { 3 - 5 } & & E. Heath & 6 & 0.9 \\
\cline { 3 - 5 } & \multirow{2}{*}{ The Brexit } & J. Corbyn & 5 & 0.9 \\
\cline { 3 - 5 } & & T. Blair & 5 & 1.03 \\
\hline Total & & & 65 & \\
\hline
\end{tabular}

Table 9. Extreme case formulations (ECFs) in the Anti- and Pro-European recordings.

\begin{tabular}{|c|c|c|c|}
\hline Position & Number of words & Number of ECFs & Ratio \\
\hline Anti-European & 3216 & 40 & 1.24 \\
\hline Pro-European & 3090 & 25 & 0.81 \\
\hline Total & 6306 & 65 & 1.03 \\
\hline
\end{tabular}




\begin{tabular}{|c|c|c|}
\hline Type of ECFs & ECFs & Number \\
\hline Negation & $\begin{array}{l}\text { Nothing is agreed, never supported, not one word, not a comma, no longer } \\
(\mathrm{x} 4) \text {, is not worth a damn, not a damn, no-of course not, never, never be } \\
\text { treated for granted. }\end{array}$ & 13 \\
\hline Globalizing & $\begin{array}{l}\text { Every part of our country, everything is agreed, every year, everything we do, } \\
\text { you've all been waiting, wholesale change, all EU citizens, all their existing } \\
\text { rights, all British citizens, all circumstances, all wages, about trading all, you } \\
\text { worried it all, we look back on all this, whole deal, all of the commonwealth, } \\
\text { whole of western Europe, whole of our democratic system, whole argument is } \\
\text { about, whole thing, whole British country, whole hearted economic effort, to } \\
\text { the whole question, here tonight to this whole, every member. }\end{array}$ & 25 \\
\hline $\begin{array}{l}\text { Adverbs of } \\
\text { frequency, } \\
\text { degree and } \\
\text { manner }\end{array}$ & $\begin{array}{c}\text { Absolutely clear, always be determined, always behind, I say absolutely, } \\
\text { completely understand, perfectly sensible, ever fighting, completely } \\
\text { different. }\end{array}$ & 8 \\
\hline Adjectives & The best, tiny, massive, huge, final, full (x2), vital, wildest, the worst. & 10 \\
\hline Numbers & Once in a lifetime, lots, my first and foremost & 3 \\
\hline Nouns & Coming to an end (x2), line by line. & 3 \\
\hline Exclusiveness & Only our courts, let alone (x2) & 3 \\
\hline Total & & 65 \\
\hline
\end{tabular}

a two-fold classification. On the one hand, we identified ECFs with three clear functions: to globalize, to negate, and to exclude. Those words which did not fall into any of these functions but which, nevertheless, were ECFs, have been classified according to their grammatical categories (adverbs, adjectives, nouns, and numbers apart). The reasons behind this decision are: (a) not to omit any ECF from our classification, (b) to highlight the three most common functions we have found (to globalize, to negate, and to exclude), and (c) to research the possible relationships between the use of one specific grammatical category (ECF) and the political stance and/or time of the plebiscite. It is obvious that one word included in the group of globalizing, negations, or exclusiveness could also belong (from a grammatical point of view) to the group of adjectives/nouns/adverbs, but there is a very differentiating factor: they do not share the same function. To sum up, the adjectives, adverbs, and nouns included in their grammatical category group do not perform any of the globalizing, negation, or exclusiveness functions, they are just expressing a radical and extremist condition.

The most numerous ECFs were the negation and the globalizing ones. This is because these two features are at the core of the contest: rejection of an undesirable situation (either belonging or not belonging to the EU) and an allegation to be everyone's choice (either the Pro- or the "Anti-European position). Thus, $i$ analyzing the frequency of of these ECFs in each political position was pertinent. Table 11 shows the results of this analysis. Regardless of the time period, negation ECFs were much more numerous in the Anti-European position ( 0.34 vs. 0.06 ; see Table 12$)$. This result was expected considering that Anti-European politicians' motto was a complete rejection of their stay in the 


\begin{tabular}{|c|c|c|c|c|}
\hline Position & Recordings & Type of ECF & $\begin{array}{c}\text { Number of negation } \\
\text { and globalizing } \\
\text { ECFs } \\
\end{array}$ & Ratio \\
\hline \multirow{4}{*}{ Anti-European } & \multirow{2}{*}{$\begin{array}{l}\text { The } 1975 \\
\text { Referendum }\end{array}$} & Negation & 10 & 0.7 \\
\hline & & Globalizing & 5 & 0.34 \\
\hline & \multirow{2}{*}{ The Brexit } & Negation & 1 & 0.05 \\
\hline & & Globalizing & 7 & 0.39 \\
\hline \multirow{4}{*}{ Pro-European } & \multirow{2}{*}{$\begin{array}{c}\text { The } 1975 \\
\text { Referendum }\end{array}$} & Negation & 2 & 0.13 \\
\hline & & Globalizing & 7 & 0.46 \\
\hline & \multirow{2}{*}{ The Brexit } & Negation & 0 & 0 \\
\hline & & Globalizing & 6 & 0.38 \\
\hline Total & & & 38 & 0.60 \\
\hline
\end{tabular}

\begin{tabular}{|c|c|c|c|}
\hline \multicolumn{4}{|c|}{ Table 12. Negation extreme case formulations (ECFs) in the Anti- and Pro-European positions. } \\
\hline Position & Number of words & $\begin{array}{c}\text { Number of Negation } \\
\text { ECFs }\end{array}$ & Ratio \\
\hline Anti-European & 3216 & 11 & 0.34 \\
\hline Pro-European & 3090 & 2 & 0.06 \\
\hline Total & 6306 & 13 & 0,21 \\
\hline
\end{tabular}

EU. However, interestingly, the Anti-European position was much more frequent in the 1975 Referendum recordings, because the rate of negation ECFs was overwhelmingly greater $(0.7)$ than in the Brexit recordings $(0.05)$. For example, consider the following excerpt from Peter Shore's parliamentary speech:

Not one word, not a comma, let alone a clause, let alone a paragraph of the Rome Treaty - not one comma has been altered in order to meet the perfectly legitimate and serious differences that exist between Britain and the Common Market ... What is the message that comes now? No longer to tell the British people about the goodies that lie there. No longer that. That won't wash - will it? Because the evidence will no longer support it. So the message, the message that comes out is fear, fear, fear ...Fear because you won't have any food. Fear of unemployment. Fear that we've somehow been so reduced as a country that we can no longer, as it were, totter about in the world independent as a nation.

In this excerpt, Shore does not only use a significant number of negative ECFs but he even repeated them for emphatic purposes. He uses up to fives times the ECF "no longer," which marks a definite and conclusive end of an adverse situation that has been going on for too long. The sentence "Not one word, not a comma, let alone a clause, let alone a paragraph of the Rome Treaty - not one comma" is stating in a radical way an apparently inflexible position when considering British idiosyncrasies in Europe. 
In the case of the globalizing ECFs, the differences were not as significant ( 0.37 for Anti-European recordings and 0.42 for Pro-European recordings; see Table 13).

Both sides share a common goal: to make their listeners feel that they are "in the same boat" and that the speaker's feeling is everyone's feeling, and, much more specifically, a British feeling. We grouped together ECFs that indicate integration (e.g., every) and those that generalize a situation to a whole group (e.g., all/whole) for reasons of economy of space. Theresa May explains in a parliamentary speech that:

It means we will be able to use that money to invest in our priorities at home, such as housing, schools and the NHS, and it means the days of paying vast sums to the European Union every year are coming to an end.

Here, May resorts to a national feeling ("our priorities at home") of welfare that was previously ignored. So, she appeals to a common wish to end up with a continuous ("every year") situation which was being detrimental to British society. On the Pro-European side, Jeremy Corbyn similarly appealed to British unity:

Importantly for British citizens living in EU countries, can the Prime Minister confirm that the Government's negotiations mean that they will maintain all their existing rights indefinitely? Will she confirm today that UK pensions will continue to be paid and uprated for all British citizens?

This is part of a long series of rhetorical questions aimed at the enhancement of British citizens' rights. Corbyn's argument is that British citizens will witness a cutback on their rights as a result of their segregation from the EU. So, again, both positions use similar globalizing strategies when trying to persuade their listeners.

Adverbs of frequency, degree, and manner and adjective ECFs also represented an important number (18 in total). Table 14 shows their detailed distribution.

Regardless of their position, all speakers showed the same distribution in the use of adverbs of frequency, degree, and manner ( 0.12 vs. 0.13$)$ and adjective ECFs ( 0.15 vs. 0.16 ; see Table 15$)$

Nevertheless, the use of ECF adjectives was always far more frequent in the 1975 Referendum regardless of the expressed position. In the case of the Anti-European position, the ratio in the 1975 Referendum was 0.21 in contrast

\begin{tabular}{|c|c|c|c|}
\hline \multicolumn{3}{|c|}{ Table 13. Globalising extreme case formulations (ECFs) in the Anti- and Pro-European positions } \\
\hline Position & Number of words & $\begin{array}{c}\text { Number of Globalizing } \\
\text { ECFs }\end{array}$ & Ratio \\
\hline Anti-European & 3216 & 12 & 0.37 \\
\hline Pro-European & 3090 & 13 & 0.42 \\
\hline Total & 6306 & 25 & 0.39 \\
\hline
\end{tabular}




\begin{tabular}{|c|c|c|c|c|}
\hline $\begin{array}{l}\text { Table 14. Distrib } \\
\text { formulations (ECF }\end{array}$ & f "adverbs & ncy, degree, & nanner" and "a & $\overline{\text { extr }}$ \\
\hline Position & Recordings & Type of ECF & $\begin{array}{c}\text { Number of } \\
\text { "Adverbs of } \\
\text { frequency, degree } \\
\text { and manner" and } \\
\text { "adjectives" ECFs }\end{array}$ & Ratio \\
\hline & The 1975 & Adverbs & 2 & 0.14 \\
\hline & Referendum & Adjectives & 3 & 0.21 \\
\hline Ant1-European & The Rreyit & Adverbs & 2 & 0.11 \\
\hline & Ine Brexit & Adjectives & 2 & 0.11 \\
\hline & The 1975 & Adverbs & 1 & 0.06 \\
\hline Pro_Furonean & Referendum & Adjectives & 3 & 0.2 \\
\hline Pro-European & The Rrexit & Adverbs & 3 & 0.19 \\
\hline & Ine brexit & Adjectives & 2 & 0.13 \\
\hline Total & & & 18 & 0.28 \\
\hline
\end{tabular}

Table 15. Adverb and adjective extreme case formulations (ECFs) in the Anti- and Pro-European position recordings.

\begin{tabular}{|c|c|c|c|}
\hline Position & Number of words & Number of Adverb ECFs & $\begin{array}{c}\text { Number of Adjective } \\
\text { ECFs }\end{array}$ \\
\hline Anti-European & 3216 & $\begin{array}{c}4 \\
\text { (Ratio: } 0.12\end{array}$ & $\begin{array}{c}5 \\
\text { (Ratio: 0.15) }\end{array}$ \\
\hline Pro-European & 3090 & $\begin{array}{c}5 \\
\text { (Ratio: } 0.13)\end{array}$ & $\begin{array}{c}10 \\
\text { (Ratio: } 0.16)\end{array}$ \\
\hline
\end{tabular}

to 0.11 in the Brexit. In the case of the Pro-European position, the ratio in the 1975 Referendum was 0.2 in contrast to 0.13 in the Brexit. Adjectives are mainly descriptive in their nature, so it seems that politicians in the 1975 Referendum contest wanted to be very descriptive and pictorial in a situation which was completely new to British citizens, and they wanted to illustrate it in the most extremist and radical way. In the following excerpt it can be seen how Harold Wilson uses the adjective vital in a political interview:

but for example in trade figures which are vital to the whole question of the balance of payments in the path and they have measurably increased in the last quarter of last year

He does not only use the extreme adjective vital, but he also uses the globalizing ECF "whole" in the same sentence. So, it seems that the tone of his speech when talking about negative economic consequences of the Common Market is completely irrefutable and radical.

In the case of the adverbs, differences were practically nonexistent. The only difference concerned the use of adverbs by politicians in the 1975 Referendum in 
the Anti- (0.14) and Pro-European (0.06) positions. Still, these differences were insignificant: two adverbs (always and absolutely) in the Anti-European position and one ("ever fighting") in the Pro-European position.

Finally, in the case of number, noun, and exclusiveness ECFs, Table 16 shows the detailed distribution data.

The ratios in this case were generally low. The only outstanding feature was that they were much more frequent in the Anti-European positions. For example, the numbers ECFs in the Anti-European position have ratios of 0.07 and 0.05 , but in the Pro-European position, the ratio is just 0.06 in the 1975 Referendum recordings and it is nonexistent in the Brexit recordings. In the case of noun ECFs, in the Anti-European recordings, position the ratio was 0 (The 1975 Referendum) and 0.17 (the Brexit), and an absolute 0 in the Pro-European position recordings. Finally, in the case of exclusiveness ECFs, in the Anti-European position, the ratio was 0.14 (The 1975 Referendum) and 0.05 (the Brexit); and an absolute 0 in the Pro-European recordings. The most revealing facts were the 0.14 ratio of exclusiveness ECFs in The 1975 Referendum (Anti-European position) and the 0.17 ratio of noun ECFs in the Brexit (Anti-Europe position). In the former case, Shore's words are very illustrating:

It was not negotiated, it was accepted. Not one word, not a comma, let alone a clause, let alone a paragraph of the Rome Treaty - not one comma has been altered in order to meet the perfectly legitimate and serious differences that exist between Britain and the Common Market.

In this excerpt, Shore wants to emphasize that nothing was negotiated, not even the smallest elements, and he pinpoints very singular elements like commas,

\begin{tabular}{|c|c|c|c|c|}
\hline Position & Recordings & Type of ECF & $\begin{array}{c}\text { Number of } \\
\text { "numbers, nouns, } \\
\text { and exclusiveness" } \\
\text { ECFs }\end{array}$ & Ratio \\
\hline \multirow{6}{*}{ Anti-European } & \multirow{3}{*}{$\begin{array}{l}\text { The } 1975 \\
\text { Referendum }\end{array}$} & Number & 1 & 0.07 \\
\hline & & Noun & 0 & 0 \\
\hline & & Exclusiveness & 2 & 0.14 \\
\hline & \multirow{3}{*}{ The Brexit } & Number & 1 & 0.05 \\
\hline & & Noun & 3 & 0.17 \\
\hline & & Exclusiveness & 1 & 0.05 \\
\hline \multirow{6}{*}{ Pro-European } & \multirow{3}{*}{$\begin{array}{l}\text { The } 1975 \\
\text { Referendum }\end{array}$} & Number & 1 & 0.06 \\
\hline & & Noun & 0 & 0 \\
\hline & & Exclusiveness & 0 & 0 \\
\hline & \multirow{3}{*}{ The Brexit } & Number & 0 & 0 \\
\hline & & Noun & 0 & 0 \\
\hline & & Exclusiveness & 0 & 0 \\
\hline Total & & & 9 & 0.14 \\
\hline
\end{tabular}


clauses, or paragraphs. He is taking to the extreme the lack of negotiations in contrast to just acceptance and resignation.

In the following example, it can be seen how Theresa May uses noun ECFs to exemplify her position against the EU:

These are the actions of a responsible nation honouring the commitments that it has made to its allies, having gone through those commitments line by

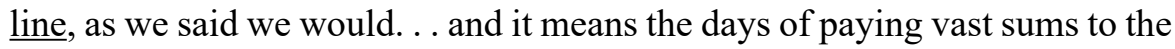
European Union every year are coming to an end

So, she describes the way to go through those commitments as "line by line," that means with no exceptions, with no veto. A few lines later, she even refers to the days to pay money to the EU as "coming to an end," and that means with no possible extension of time. So, she is definite, radical, and conclusive in her speech, admitting no exceptions to her position. As has been previously mentioned, more radical positions are being preferred by the Anti-European politicians. They want to show a total negation to the situation they are showing as radically negative to British interests.

In the following excerpt taken from Shore's parliamentary speech against the permanence of the UK in the EU, the way he frames a radical reality can be seen:

The whole thing is an absurdity! And therefore I urge you, I urge you to reject it. I urge you to say 'No' to this motion! And I urge the whole British country to say 'No' on Thursday in the referendum!

Shore does not use expressions like "the thing is absurd" or "the British country." Instead, he says, "the whole thing" and "the whole British country." In this way, the scopes of "thing" and "British country" are extended to the maximum. Similarly, he does not say "I ask you." Instead, he says "I urge you" up to three times. In contrast to "ask," "urge" conveys severe insistence because it means to advise someone very strongly about something. He uses "I urge you" three times because this number is related to a very well-known political rhetorical device called the three-part list. According to Heritage \& Greatbatch (1986, p. 116), it is "regularly used in political speeches and regularly associated with the generation of applause." As Atkinson (1984, p. 60) points out, repetition helps "to strengthen, underline, or amplify almost any kind of message." Finally, Shore uses the negation "no" twice and the verb to reject, which projects absolute disagreement. So, this excerpt transmits a total, radical, and extremist rejection to the permanence of the UK in the EU. As Abelson (1995, p. 25) explains, "one social arena in which extreme attitudes are consequential is that of intergroup conflict, because conflict can breed attitude extremity, which in turn serves to maintain or increase conflict." It is a widely known fact that the political arena is a conflict arena per se. By means of these strategies, Shore is framing a particular 
reality that absolutely and totally rejects the permanence of the UK in the EU.

\section{Conclusion}

The main goal of this paper was to discover if politicians in the 1975 Referendum and the Brexit: (a) framed a similar or different reality through their discourse choices and (b) used the same types of adverbs of certainty and ECFs with the same frequency.

The first conclusion is that even though there were some similarities regarding their discourse choices (e.g., regardless of the time or the position, the politicians were more prone to display extreme opinions than to demonstrate certainty), there were some differences. For instance, the low ratio of adverbs of certainty in the Anti-European 1975 Referendum (0.07) and the high ratio of ECFs in the Anti-European 1975 Referendum (1.61). This connects with Gross et al.'s (1995, p. 218) comment that "extremity and certainty share conceptual and empirical meaning, but whereas extremity connotes certainty, certainty does not necessarily imply extremity." As a matter of fact, the Anti-European position (no matter the time) was always much more inclined to use ECFs (1.24 vs. 0.81). It could be related to the view of the reality they wanted to frame: negation, detachment, and renunciation to a settled situation.

The second conclusion concerns the use and frequency of same types of adverbs of certainty and ECFs. The first result is related to the low rate of adverbs of certainty (0.17) in contrast to the high rate of ECFs (1.03). As we pointed out, this shows that politicians, no matter the time (The 1975 Referendum or The Brexit) or the position (Anti- or Pro-European), are more prone to display extreme opinions than to demonstrate certainty. When it comes to ECFs, the most frequent ones were the globalizing ECFs (0.39) followed by the negation ECFs (0.21). Globalizing ECFs followed a similar distribution in both, the Anti$(0.37)$ and the Pro-European (0.42) positions. As it was previously stated, in both cases the aim is the same: to make their voters feel that they share the same nationalistic feelings, no matter if you are in the Anti- or in the Pro-European position. Negation ECFs were not distributed as evenly: regardless of the time, negation ECFs were much more frequent in the Anti-European position ( $0.34 \mathrm{vs}$. 0.06). As it was mentioned, this result is predictable if we take into consideration that their motto was a kind of "No Europe."

To sum up, we can confirm Edwards' words (2004. p. 260) that "people are shown to formulate or work up the nature of events, actions, and their own accountability, through ways of talking. These "ways of talking" are constructive and action-oriented." That is to say, there is a strong connection between the selection of our words and the reality we build. Language and reality are two enduring sides of the same coin. As we have already indicated, Scheufele (1999) argued that individuals can frame their own reality, and this is particularly evident in the case of political communication. Taking into account Kaid et al.'s (1991) 
description of the components of political reality (i.e. (an objective reality; a subjective reality and a constructed reality), in this particular scenario, the objective reality is the potential exit of the UK from the EU, the subjective reality is made up of the politicians' perceptions of this reality, a reality that they frame by means of their specific discursive choices; and the constructed reality is the reality that the media frame, also by means of their specific discursive choices.

Nevertheless, it is not the intention of this paper to present general and definite claims about the 1975 Referendum- and the Brexit-specific styles but rather to show the different discursive strategies used by politicians when they try to build their own objective interpretation of a single common reality.

\section{Acknowledgments}

The author declares no acknowledgments.

\section{Conflict of Interest Disclosure}

The author declares no conflicts of interest.

\section{Funding}

The author declares no sources of funding.

\section{Research Ethics Statement}

The author declares no research ethics statement and/or no such statement is required or applies. 


\section{References.}

Akiba, D. (2016). On modal interpretations in noun phrases. Sophia Linguistica, 65.

Atkinson, J. M. (1984). Our masters'voices: The language and body language of politics. Methuer.

Ball, T. (2011). Manipulation: As old as democracy itself (and sometimes dangerous). In W. Le Cheminant, \& J. M. Parrish (Eds.), Manipulating democracy: Democratic theory, political psychology, and mass media (pp. 4158). Routledge.

Biber. D., Johansson, S., Leech, G., Conrad, S., \& Finegan, E. (1999). The Longman grammar of spoken and written English. Longman.

Brim, O. G. (1955). Attitude content-intensity and probability expectations. American Sociological Review, 20(1), 68-76.

Campos, N. F., Coricelli, F., \& Moretti, L. (2014). Economic growth and political integration: Estimating the benefits from membership in the European Union using the synthetic counterfactuals method. Institute for the Study of Labor, IZA Discussion Paper, No. 8162.

Chouliaraki, L. (2005). The soft power of war. Journal of Language and Politics, $4(1), 1-10$.

Coates, J. (1983). The semantics of the modal auxiliaries. Croom Helm.

Deacon, D. (2016). 82\% circulation advantage in favour of Brexit as The Sun declares. Centre for Research in Communication and Culture, Loughborough University, June 14.

Denton, R. E., \& Woodward, G. C. (1990). Political communication in America. Praeger.

Dontcheva-Navratilova, O. (2018). Intercultural and interdisciplinary variation in the use of epistemic lexical verbs in linguistics and economics research articles. Linguistica Pragensia, 28(2), 154-167.

Edwards, D. (2000). Extreme case formulations: Softeners, investment, and doing nonliteral. Research on Language and Social Interaction, 33(4), 347-373.

Edwards, D. (2004). Discursive psychology. In K. Fitch, \& R. Sanders (Eds.), Handbook of language and social interaction. Lawrence Erlbaum Associates.

Edwards, D., \& Potter, J. (1992). Discursive psychology. Sage Publications, Inc. Entman, R. M. (1993). Framing: Towards clarification of a fractured paradigm. Journal of Communication, 43(4), 51-58.

Entman, R. M. (2004). Projections of power: Framing news, public opinion, and U.S. foreign policy. University of Chicago Press.

Gorodnichenko, Y., Pham, T., \& Talavera, O. (2018). Social media, sentiment and public opinions: Evidence from \#Brexit and \#USElection”. (May 2018). Working Paper 24631. National Bureau of Economic Research.

Gross, S. R., Holtz, R., \& Miller, N. (1995). Attitude certainty. In J. A. Krosnick, $\&$ R. E. Petty (Eds.), Attitude strength: Antecedents and consequences (pp. 
215-245). Erlbaum Associates.

Guttman, L., \& Suchman, E. A. (1947). Intensity and a zero point for attitude analysis. American Sociological Review, 12(1), 57-67.

Hänska, M., \& Bauchowitz, S. (2017). Tweeting for Brexit: How social media influenced the Referendum. In J. Mair, T. Clark, N. Fowler, R. Snoddy, \& R. Tait (Eds.), Brexit, Trump and the media (pp. 31-35). Abramis Academic Publishing.

Heritage, J., \& Greatbatch, D. (1986). Generating applause: A study of rhetoric and response at party political conferences. American Journal of Sociology, 92(1), 110-157.

Herrman, J. (2016). 'Brexit' talk on social media favored the 'Leave' side. New York Times, July 16.

Huddleston, R., \& Pullum, G. (2002). The Cambridge grammar of the English language. Cambridge University Press.

Ilkhanipour, N. (2016). Tense and modality in the nominal domain. Linguistica, 56(1), 143-160.

Kaid, L. L., Gerstle, J., \& Sanders, K. R. (Eds.). (1991). Mediated politics in two cultures: Presidential campaigning in the United States and France. Praeger.

Katz, D. (1944). The measurement of intensity. In H. Cantril (Ed.), Gauging public opinion (pp. 51-65). Princeton University Press.

Kinder, D. R. (2007). Curmudgeonly advice. Journal of Communication, 57(1), $155-162$.

McDill, E. L. (1959). A comparison of three measures of attitude intensity. Social Forces, 38(2), 95-99.

McNair, B. (2011). An introduction to political communication. Taylor and Francis.

Melkumian, A. A. (2018). A note on the demographics of UK referendums on "staying or leaving the European Union". The Journal of Applied Business and Economics, 20(5), 40-45.

Minford, P. (2006). Measuring the economic costs and benefits of the EU. Open Economies Review, 17(4-5), 509-524.

Nye, J. (2004). Soft power. The means to success in world politics. Public Affairs.

Ottaviano, G. I., Pessoa, J.P., Sampson, T., \& Van Reenen, J. (2014). The costs and benefits of leaving the EU. Center for Financial Studies Working Paper Series, 472, 1-18.

Pain, N., \& Young, G. (2004). The macroeconomic impact of UK withdrawal from the EU. Economic Modeling, 21(3), 387-408.

Palmer, F. (1990). Modality and the English modals. Longman.

Perloff, R. M. (2018). The dynamics of political communication. Media and politics in a digital age. Routledge.

Polonski, V. (2016). Social media voices in the UK's EU referendum. Medium, May 15.

Pomerantz, A. (1986). Extreme case formulations: A way of legitimizing claims. 
Human Studies, 9(2-3), 219-229.

Quirk, R., Sidney, G., Leech, G., \& Svartvik, J. (1985). A comprehensive grammar of the English language. Longman.

Rozumko, A. (2017). Adverbial markers of epistemic modality across disciplinary discourses: A contrastive study of research articles in six academic disciplines. Studia Anglica Posnaniensia, 52(1), 73-101.

Salazar, D., \& Verdaguer, I. (2009). Polysemous verbs and modality in native and non-native argumentative writing: A corpus-based study. International Journal of English Studies, 9(3), 209-219.

Scheufele, D. A. (1999). Framing as a theory of media effects. Journal of Communication, 49(1), 103-122.

Simon-Vandenbergen, A., \& Aijmer, K. (2007). The semantic field of modal certainty. A corpus-based study of English adverbs. Mouton de Gruyter.

Suchman, E. A. (1950). The intensity component in attitude and opinion research. In S. A. Stouffer, L. Guttman, E. A. Suchman, P. F. Lazardsfeld, S. A. Star, \& J. A. Clausen (Eds.), Measurement and prediction (pp. 213-276). Princeton University Press.

Tannenbaum, P. H. (1956). Initial attitude toward source and concept as factors in attitude change through communication. Public Opinion Quarterly, 20(2), 413-425.

Tendera-Właszczuk, H. (2018). Study on the brexit's background and causes. Ekonomia i Prawo, 17(3), 307-317.

Van linden, A. (2012). Modal adjectives: English deontic and evaluative constructions in diachrony and synchrony. Mouton de Gruyter

Velasquez Chafloque, H. (2014). A reduplicative analysis of sentence modal adverbs in Spanish. PhD Thesis. University of Southern California.

Whitehead, K. A. (2015). Extreme-case formulations. In K. Tracy, C. Ilie, \& T. Sandel (Eds.), The international encyclopedia of language and social interaction (pp. 1-5). John Wiley \& Sons.

Zhang, J. (2019). A semantic approach to the English modality. Journal of Language Teaching and Research, 10(4), 879-885.

Zhuravskaya, E., Petrova, M., \& Enikolopov, R. (2020). Political effects of the Internet and social media. Annual Review of Economics, 12, 415-438. 